Article

\title{
Cementitious Behavior of Argon Oxygen Decarburization Stainless Steel Slag and Its Stabilization on Chromium
}

\author{
Ya-Jun Wang ${ }^{1,2}{ }^{\mathbb{D}}$, Ya-Nan Zeng ${ }^{2, *}$, Jun-Guo Li $^{2, *}$ and Yu-Zhu Zhang ${ }^{1,2}$ \\ 1 School of Materials and Metallurgy, Northeastern University, Shenyang 110819, China; \\ 1710516@stu.neu.edu.cn (Y.-J.W.); zyz@ncst.edu.cn (Y.-Z.Z.) \\ 2 School of Metallurgy and Energy, North China University of Science and Technology, \\ Tangshan 063009, China \\ * Correspondence: zengyanann@126.com (Y.-N.Z.); lijg99@163.com (J.-G.L.)
}

Received: 24 August 2020; Accepted: 25 September 2020; Published: 27 September 2020

\begin{abstract}
The study mainly aims at the potential of Argon Oxygen Decarburization Slag (AODS) as a supplementary cementitious material and explores the mechanisms of stabilization/solidification (S/S) of chromium in cement-based composite pastes. The basic cementitious parameters, such as water requirement, setting time, soundness, hydration characteristics, and strength indexes of composite binders, were examined through standard methods. The results showed that the most beneficial mineral phase in AODS for cementitious behavior was beta dicalcium silicate $\left(\beta-C_{2} S\right)$. The utilization of a higher AODS dosage in composite binders increased the water requirement and the setting time, while it decreased the hydration heat and the strength indexes. Although the AODS possessed limited cementitious properties, it conformed the Grade II steel slag powder qualified for concrete and cement. Sequential leaching tests were conducted targeting the leachability of chromium in the pastes with different AODS dosage and curing time. Results showed that with the lower AODS dosage and the longer curing time, the $\mathrm{S} / \mathrm{S}$ efficiency for chromium leaching from the composite paste was better. Utilization of AODS as a cement substitute not only can recycle this solid waste and decrease the emission of $\mathrm{CO}_{2}$ concerning cement production, but also helps to effectively reduce the chromium leaching risk.
\end{abstract}

Keywords: AOD slag; cementitious property; stabilization/solidification; chromium; leachability

\section{Introduction}

Stainless-steel slag includes Electric Arc Furnace Slag (EAFS), Argon Oxygen Decarburization Slag (AODS), and Ladle Metallurgy Slag (LMS) [1]. AODS is generated in an AOD furnace in the refining process of stainless-steel. It has a high content of $\mathrm{CaO}, \mathrm{SiO}_{2}$, and $\mathrm{MgO}$, as well as some $\mathrm{Cr}_{2} \mathrm{O}_{3}$ and fluorine [2]. In its cold state, the crystalline mineral phase composition of AODS is mainly $\gamma$-dicalcium silicate $\left(\gamma-\mathrm{C}_{2} \mathrm{~S}\right), \beta$-dicalcium silicate $\left(\beta-\mathrm{C}_{2} \mathrm{~S}\right)$, periclase and fluorite, traces of $\mathrm{f}-\mathrm{CaO}$, merwinite, and spinel [3]. In the cooling process, $\mathrm{C}_{2} \mathrm{~S}$ transforms from $\beta$-type to $\gamma$-type around $490{ }^{\circ} \mathrm{C}$ [4]. This mineral phase transformation causes an increase of about $12 \%$ in volume, causing shattering of the crystals and generating the powdery AODS [5]. The quantity of AODS produced in China annually accounts for about 1.8 million tons, containing an approximate amount of 9540-ton chromium (Cr) [6]. Once the $\mathrm{Cr}$ enters the environmental cycle, trivalent $\mathrm{Cr}$ can be oxidized to hexavalent $\mathrm{Cr}$ with oxygen [7]. Hexavalent $\mathrm{Cr}$ has been identified as a toxicant that can induce carcinogenic and toxic impacts through a complex multiple mechanism of action including mutagenesis, oxidative stress, damage on chromosome and DNA, and epigenetic changes [8]. 
The physicochemical properties of alternative materials determine their potential as cementitious additives in cement-based binders $[9,10]$. According to the physical and chemical characteristics of AODS, it can be classified as a kind of industrial by-product that can be used in cement-based applications [11]. The types and contents of oxides in AODS are like Portland cement (PC). Due to the presence of hydratable $\mathrm{C}_{2} S$ phases, AODS has cementitious properties [12]. In previous research, the specific surface area of fresh AODS was determined to be $511 \mathrm{~m}^{2} / \mathrm{g}$ [13], which facilitates its application as a cement substitute [14].

It is vital to observe that $\gamma-\mathrm{C}_{2} \mathrm{~S}$ is the major $\mathrm{C}_{2} \mathrm{~S}$ form in the AODS, accounting for approximately $38 \%$ of the slag mass [15]. In general, $\gamma-C_{2} S$ is difficult to hydrate, and its hydration ratio in aqueous media for five years is only $20-25 \%$ [16]. $\beta-\mathrm{C}_{2} \mathrm{~S}$ is hydraulic, but its content in AODS is much lower than that of $\gamma-C_{2} S$ [17]. Therefore, the application potential of $\gamma-C_{2} S$ in cement-based materials directly determines the applicability of AODS. $\gamma-\mathrm{C}_{2} \mathrm{~S}$ can be easily carbonated without hydration when in contact with $\mathrm{CO}_{2}$ and water [18]. Using carbonation properties, many researchers have found that $\gamma-\mathrm{C}_{2} \mathrm{~S}$ can be used as a durability modifier for a cement-based product. Mabudo et al. [19] researched the properties and structure of cement-based mortars and pastes with different $\gamma-C_{2} S$ supplementary ratios under atmospheric carbonation curing and found that carbonation curing reduced porosity by about $33 \%$ and improved the mechanical properties of composite materials from $50 \mathrm{MPa}$ to $70 \mathrm{MPa}$. For cement-based products with lower initial strength but higher durability requirements, it may be a good choice to use AODS as a cementitious substitute.

The significance of applying such industrial waste as a cement substitute is that it can save landfill space $[20,21]$ and decrease $\mathrm{CO}_{2}$ emissions in the cement production [22-24]. Except for cementitious characteristics, the potential environmental issues related to the leaching risk of chromium must be considered when AODS was utilized as a cement substitute. The recycling of AODS was very limited due to its high $\mathrm{Cr}$ content $(0.5-5 \mathrm{wt} . \%)[13,25-27]$. Studies have shown that the chromium leaching risk of AODS is usually underestimated [7]. Under certain leaching conditions, the concentration of chromium in the leachates obtained from the AODS products is enough to pose an ecological risk [28].

The stabilization/solidification (S/S) process is one of the effective technologies to treat industrial wastes containing hazardous materials [29-33]. The S/S process plays its role by mixing solid waste with cementitious materials to reduce mobility, as well as the toxicity of the contaminants [32,34], and this process usually accompanies encapsulation, absorption, precipitation, and finally detoxification [35,36]. $\mathrm{S} / \mathrm{S}$ by cementitious materials like cement is in an extensive application for immobilization of chromium $[37,38]$. Chromium can be efficiently immobilized by the hydration products of the cured cement-based composite cementitious materials [39]. Applying the AODS as the partial substitute for cement is an S/S process. The existence of chromium in AODS has its characteristics [40], but researchers also need to obtain information on how chromium is present in the cement-based composite material that has undergone the S/S process to beneficial assessing chromium leachability. While studying the maximum applicability of AODS in cement, it is also necessary to consider the potential ecological risks of chromium introduced by the incorporated AODS [26].

The specific focus of this research is on evaluating the cementitious property of AODS and analyzing the S/S effect on the chromium sequestration in the cement-based composite binders with different AODS dosages. The water requirement, setting time, soundness, and activity indexes of composite binders were tested by using a series of standard test approaches. The hydration heat evolution of composite binders was monitored adopting a TAM-Air isothermal calorimeter. Changes of mineral phases and their microstructures of the hydrated pastes were analyzed through Fourier-transform infrared (FT-IR) spectroscopy, scanning electron microscopy (SEM/EDS), and X-ray diffraction (XRD). The hydration ratios of the pastes were determined by thermogravimetric (TG/DTG) analysis. Moreover, a sequential leaching test (EN-12457) was conducted to acquire information concerning $\mathrm{Cr}$ leachability in the pastes with various AODS supplemental and hydration ratios. 


\section{Experiment}

\subsection{Raw Materials}

The material of AODS was directly collected in the stainless-steel refining workshop. The received AODS presented a powdery appearance with disaggregated particles. After being sieved by using a 120-mesh sieve, the AODS was continuously dried at a constant temperature of $105^{\circ} \mathrm{C}$ for more than $5 \mathrm{~h}$ and later stored in a vacuum-sealed and dry environment.

The 42.5 strength grade Portland cement (PC), which conformed to the Chinese National Standard (CNS) GB175-2007, was used as the reference cementitious material. The chemical analysis of AODS and PC was carried out by using an Axios advanced X-ray fluorescence spectrometer (PANalytical B.V., Almelo, Netherlands), the result was quantified in oxide form. The free lime contents of AODS and PC were tested by the ethylene glycol method [41].

The distributions of particle size of AODS and PC were determined with a Mastersizer 2000 laser granularity meter (Malvern Panalytical, Malvern, UK). Absolute ethanol was used as the dispersion medium in the test.

The mineralogical compositions of AODS and PC were measured based on a combined method of XRD and FT-IR. The XRD test was performed on a D8 Advance X-ray diffractometer (Bruker Corporation, Billerica, Massachusetts, USA), and diffraction patterns were evaluated in the $2 \theta$ range of $10^{\circ}$ to $90^{\circ}$. The crystalline phases were identified using JADE 9 software based on the ICDD Powder Diffraction File (PDF-2009) database. Fourier-transform infrared (FT-IR) measurements were performed on the composition of mineral phases, which played the role of supplementary verification. The vibration and rotational spectra of molecular in the samples were measured by using a Nexus FT-IR spectrometer (Thermo Nicolet, Madison, Wisconsin, USA) in the wave range of $4000-400 \mathrm{~cm}^{-1}$.

\subsection{Paste Samples}

The reference binder (B0) was prepared from pure PC and five AODS dosages were adopted to prepare the test binders (B1, B2, B3, B4, and B5). Each dry binder was mechanically mixed in a blender for $30 \mathrm{~min}$ to reach complete homogeneity.

The normal consistency water requirement, the setting time, and the soundness of binders were tested in line with the CNS GB/T 1346-2011 (ISO 9597: 2008). The cementitious properties of AODS were obtained initially by analyzing the effects of AODS dosage on these three basic cementitious indexes. All of the analyses were performed in duplicate.

The hydration exotherm rates, together with the cumulative exotherms of the composite binders, were monitored through an isothermal calorimeter (TAM Air from TA Instruments) according to ASTM C1702 [42]. The ratio of water to binder was set to $0.4 \mathrm{~mL} / \mathrm{g}$ and the measurements were implemented at the constant temperature environment of $20^{\circ} \mathrm{C}$ within $96 \mathrm{~h}$.

To systematically study the hydration products of the composite binder, the wet composite pastes were produced by mixing the composite binders and water with water to binder ratio of $0.4 \mathrm{~mL} / \mathrm{g}$. Then, the composite pastes were immediately sealed in plastic wraps. At test ages, absolute ethanol was used to immerse the hardened pastes to avoid further hydration before exsiccation of them in a vacuum drying oven at $50{ }^{\circ} \mathrm{C}$ for $48 \mathrm{~h}$ before further testing.

The measurement of hydrated pastes' mineral phases was conducted by XRD coupled with FT-IR, and the experimental parameters were described previously. The morphology and micromorphology of hardened pastes were scanned by the usage of a Quanta 650 FEG electron microscopy (Thermo Fisher, Waltham, MA, USA). The elemental compositions of representative products in hardened pastes were measured through energy-dispersive X-ray spectroscopy (EDS).

The hydration degree was determined by TG-DTG analysis. The analysis of TG was conducted by using a Setsys evo TG analyzer (Setaram, Lyon, France). Using a cylindrical A12O3 crucible as a sample container, we heated the paste samples from ambient temperature to $950{ }^{\circ} \mathrm{C}$ protected by nitrogen atmosphere, and the heating rate was set to $0.33^{\circ} \mathrm{C} / \mathrm{s}$. 


\subsection{Mortar Samples}

The mortar was prepared by one part of the mixing binder $(450 \pm 2 \mathrm{~g})$, three parts of ISO reference standard sand $(1350 \pm 5 \mathrm{~g})$, and one-half part of deionized water $(225 \pm 1 \mathrm{~g})$. After complete mixing, the resultant mortar was molded into three same shaped specimens by using a standard mold of $40 \mathrm{~mm} \times 40 \mathrm{~mm} \times 160 \mathrm{~mm}$, which contained three same prismatic shape grooves. After being compacted on a jolting table, the molds containing the mortars were cured in a room with a temperature of $20 \pm 1{ }^{\circ} \mathrm{C}$ and relative humidity higher than $95 \%$ for $24 \mathrm{~h}$, then the hardened mortar specimens were de-molded and then cured underwater at $20 \pm 1{ }^{\circ} \mathrm{C}$ for time intervals of 3,7 , and 28 days (including the $24 \mathrm{~h}$ for the setting). For parallel experiments, the binder of each AODS-PC formula was made into two sets of mortar specimens with the standard mold.

The reference mortar sample was prepared by using binder B0; other mortars with different AODS-PC dosages were prepared as test mortars. Compressive and flexural strength were tested upon mortar samples after curing for 3, 7, and 28 days. The activity indexes of these binders were calculated by Equation (1):

$$
A=R_{i} / R_{0} \times 100
$$

where A denotes the activity index of the AODS, $R_{i}$ denotes the strength value of the test mortar at the corresponding curing age, while $\mathrm{R}_{0}$ denotes the strength value of the reference mortar at the corresponding curing age.

\subsection{Sequential Leaching}

To study the effect of cementitious solidification on the leachability of chromium in composite binders, the sequential leaching tests designed according to European Standard EN12457-2 were conducted on pastes with different AODS dosages and hydration ratios.

\subsubsection{Leaching Subjects}

Hardened pastes prepared from B1, B2, B3, B4, and B5 curing for 28 days were dried at $105^{\circ} \mathrm{C}$ for $6 \mathrm{~h}$ and then processed by crushing and grinding until the maximum particle size was $<80 \mu \mathrm{m}$. The obtained paste powders labeled as P1, P2, P3, P4, and P5 were used as the leaching subjects to study the effect of cementitious solidification on chromium leachability.

In addition to the dosage of the cementitious admixture, the hydration ratio-which was positively related to the curing time-was another important factor affecting the $\mathrm{S} / \mathrm{S}$ on chromium leachability. Hardened pastes prepared from B5 after curing for 3, 7, and 28 days were chosen as the subjects to analyze the effect of the solidification process relating to hydration ratio on chromium leachability. The B5 dry powder without hydration was used as the reference leaching subject.

\subsubsection{Leaching Procedure}

Ten grams of hardened paste powder was weighed and placed into a 250-mL conical flask, with $100 \mathrm{~mL}$ deionized water added into the same flask. Then a lid was used to seal the flask to prevent the intrusion of oxygen and carbon dioxide. Then the sealed flask was fixed in a ZD-85 type oscillator, which can roller-table, inducing rotation of the conical flask at $10 \mathrm{rps}$. It was a 20-day sequential leaching test in a condition of room temperature. Every $24 \mathrm{~h}$ an $80 \mathrm{~mL}$ supernatant was aspirated for electrochemical and chromium concentration tests. To keep the L/S ratio at the same level in each sampling cycle, $80 \mathrm{~mL}$ of deionized water was supplemented accordingly every day.

After filtered, the leachate's electrochemical characteristics containing $\mathrm{pH}$, redox potential (Eh), and electrical conductivity were examined. In addition, chromium concentration of the leachate was tested by inductively coupled plasma-optical emission spectrometry (ICP-OES) with a detection limit of $0.004 \mathrm{mg} / \mathrm{L}$. All of the analyses were performed in duplicate. 


\section{Results and Discussion}

\subsection{Properties of Raw Materials}

The chemical compositions of the AODS and PC are presented in Table 1. The main components in both $\mathrm{AODS}$ and $\mathrm{PC}$ were $\mathrm{CaO}$ and $\mathrm{SiO}_{2}$, which made up more than $85 \%$ of the total mass. Higher $\mathrm{SO}_{3}$ content in PC than AODS was due to the additional plaster provided in the clinker to slow down the early setting rate. The $\mathrm{Cr}_{2} \mathrm{O}_{3}$ content in the studied AODS was 0.5\%, which was in the normal range [43]. The free lime content of AODS was $0.33 \%$, even lower than that of PC. Thus, expansion due to hydration of the free lime was neglectable [44].

Table 1. Chemical composition of the Argon Oxygen Decarburization Slag (AODS) and Portland cement (PC) (wt. \%).

\begin{tabular}{cccccccccc}
\hline Oxides & $\mathrm{CaO}$ & $\mathrm{SiO}_{2}$ & $\mathrm{MgO}$ & $\mathrm{Al}_{2} \mathrm{O}_{3}$ & $\mathrm{Fe}_{2} \mathrm{O}_{3}$ & $\mathrm{SO}_{3}$ & $\mathrm{Cr}_{2} \mathrm{O}_{3}$ & $\mathrm{TiO}_{2}$ & $\mathrm{f}-\mathrm{CaO}$ \\
\hline AODS & 65.78 & 24.15 & 6.55 & 1.74 & 0.26 & 0.54 & 0.50 & 0.22 & 0.33 \\
\hline PC & 65.80 & 19.12 & 1.90 & 5.15 & 3.37 & 3.10 & 0.01 & 0.31 & 0.41 \\
\hline
\end{tabular}

The particle size distributions of AODS and PC are shown in Figure 1. The particle size distribution interval was mainly between $0.5 \mu \mathrm{m}$ and $80 \mu \mathrm{m}$. The AODS had more fine particles $(<11 \mu \mathrm{m})$ and fewer coarse particles $(>11 \mu \mathrm{m})$, and as a result, the mean particle size of the AODS was smaller than that of the PC. Specific surface areas reported by calculation software for AODS and PC were $511 \mathrm{~m}^{2} / \mathrm{kg}$ and $418 \mathrm{~m}^{2} / \mathrm{kg}$, respectively.

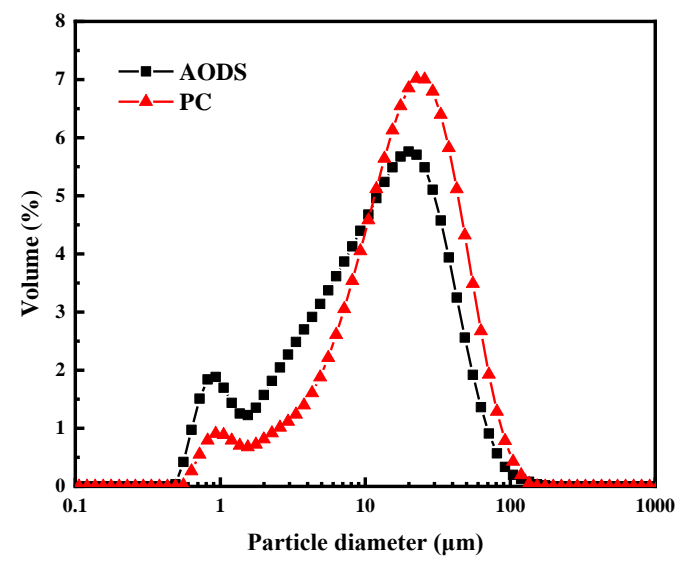

Figure 1. The particle size distribution of AODS and PC.

The XRD patterns of AODS and PC are presented in Figure 2. It was found that dicalcium silicate was the predominant mineral phase in AODS, while fluorite, periclase, merwinite, and chromium spinel were also detected, supporting conclusions of other researches on AODS [3,13]. The four typical clinker mineral phases, including dicalcium silicate, tricalcium silicate, tricalcium aluminate, and calcium aluminoferrite, were all detected in the PC [45].

The FT-IR pattern of AODS is presented in Figure 3. By analyzing the FT-IR pattern, detailed information about the $\mathrm{C}_{2} \mathrm{~S}$ phase in the AODS was examined. The bonds around $927 \mathrm{~cm}^{-1}$ and $816 \mathrm{~cm}^{-1}$ corresponded to $\gamma-C_{2} S$, while the bond around $841 \mathrm{~cm}^{-1}$ corresponded to $\beta-C_{2} S$ [13].

On the basis of the results of the XRD and FT-IR analyses, the $\mathrm{C}_{2} \mathrm{~S}$ occurred in two allotropic forms $\left(\beta-C_{2} S\right.$ and $\left.\gamma-C_{2} S\right)$ in AODS. The content of the hydratable $\beta-C_{2} S$ was much lower than the almost non-hydratable $\gamma-C_{2} S$. 


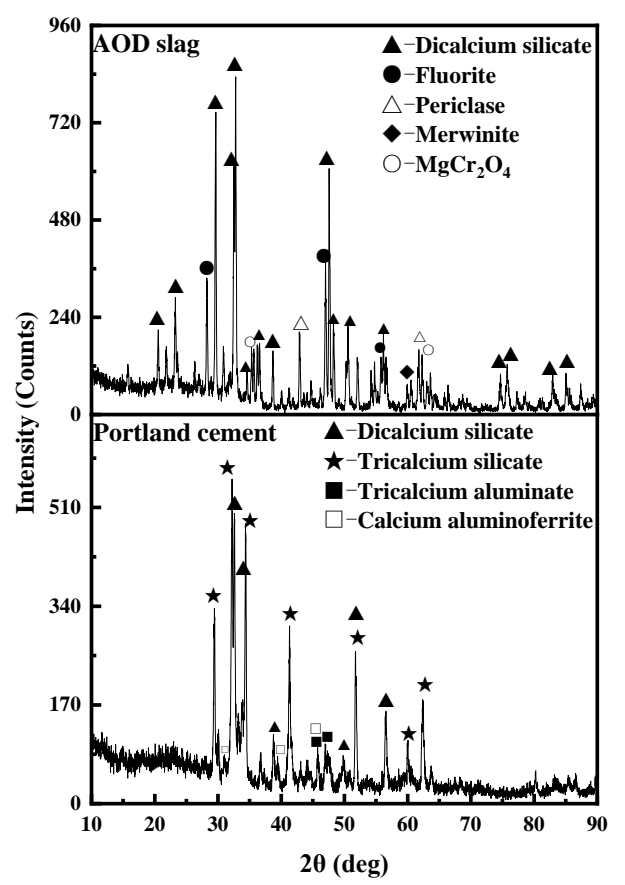

Figure 2. X-ray diffraction (XRD) results of the AODS and PC.

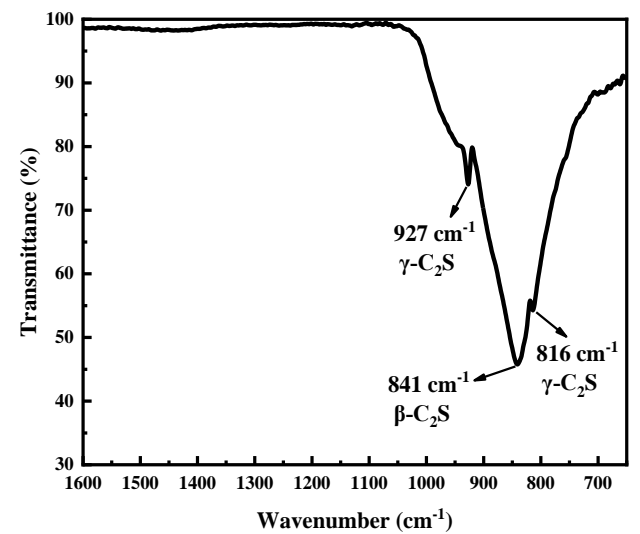

Figure 3. Fourier-transform infrared (FT-IR) patterns of the AODS.

\subsection{Cementitious Properties of AODS}

3.2.1. Water Requirement, Soundness, and Setting Time

The water requirement, setting time, and soundness tests were performed on the composite pastes, and the results are presented in Table 2.

Table 2. Cementitious properties of binders with different formulas.

\begin{tabular}{cccccccc}
\hline Binder & $\begin{array}{c}\text { AODS } \\
\text { (g) }\end{array}$ & $\begin{array}{c}\text { PC } \\
\text { (g) }\end{array}$ & $\begin{array}{c}\text { Water } \\
\text { Requirement (\%) }\end{array}$ & $\begin{array}{c}\text { Initial Setting } \\
\text { Time (min) }\end{array}$ & $\begin{array}{c}\text { Final Setting } \\
\text { Time (min) }\end{array}$ & $\begin{array}{c}\text { Expansion } \\
\text { Ratio (\%) }\end{array}$ & $\begin{array}{c}\text { Soundness } \\
\text { Determination }\end{array}$ \\
\hline B0 & 0 & 450 & 27.5 & 144 & 216 & 0.35 & Qualified \\
B1 & 50 & 400 & 29.11 & 163 & 231 & 0.30 & Qualified \\
B2 & 100 & 350 & 30.52 & 181 & 246 & 0.34 & Qualified \\
B3 & 150 & 300 & 31.73 & 190 & 265 & 0.38 & Qualified \\
B4 & 200 & 250 & 32.54 & 198 & 282 & 0.41 & Qualified \\
B5 & 250 & 200 & 33.06 & 203 & 301 & 0.43 & Qualified \\
\hline
\end{tabular}


The water requirement contents of the composite pastes to reach standard consistency were positively correlated with the dosage of AODS. When the dosage of AODS reached $55.55 \%$, the water requirement content increased from $27.5 \%$ of pure cement (B0) to $33.06 \%$ of $\mathrm{B} 5$.

The specific surface area of the PC was smaller than that of AODS. AODS particles required more surface-coated water than cement, which would lead to insufficient water content in the slurry to provide a lubrication function. Consequently, more water would be required for the paste to achieve the same consistency with the increase of AODS dosage.

The soundness of paste containing AODS is a critical parameter when it is used as the admixture for a binder. Soundness can be determined by the ability of the paste to maintain its volume after hardening. From the results presented in Table 2, it can be concluded that the AODS meets the soundness requirements (expansion ratios were $<0.50 \%$ ) specified by the CNS GB/T 750-92. This is mainly because of the free lime content of AODS only being $0.33 \%$, meeting the standard requirement of less than $3 \%$.

Table 2 shows that all the composite binders met the PC setting time specified in the CNS GB 175-2007. With the increasing of cement replacement ratio, the setting time was longer. This phenomenon was similar to the result reported in the previous literature [46]. AODS possess lower hydratable mineral content, but a larger specific surface area than PC. Therefore, as the incorporation ratio of AODS was increased, the total interface area between binder particles in the slurry state paste increased gradually. More C-S-H gel was required to produce more bonding functions at the interfaces to reach the setting state, but the added AODS cannot produce enough C-S-H gel to make up for this demand. Consequently, the setting time of the composite paste was prolonged by AODS admixture.

\subsubsection{Hydration Exotherm}

The hydration exothermic rate and cumulative hydration heat of the composite binders with different AODS dosages are presented in Figures 4 and 5, respectively.
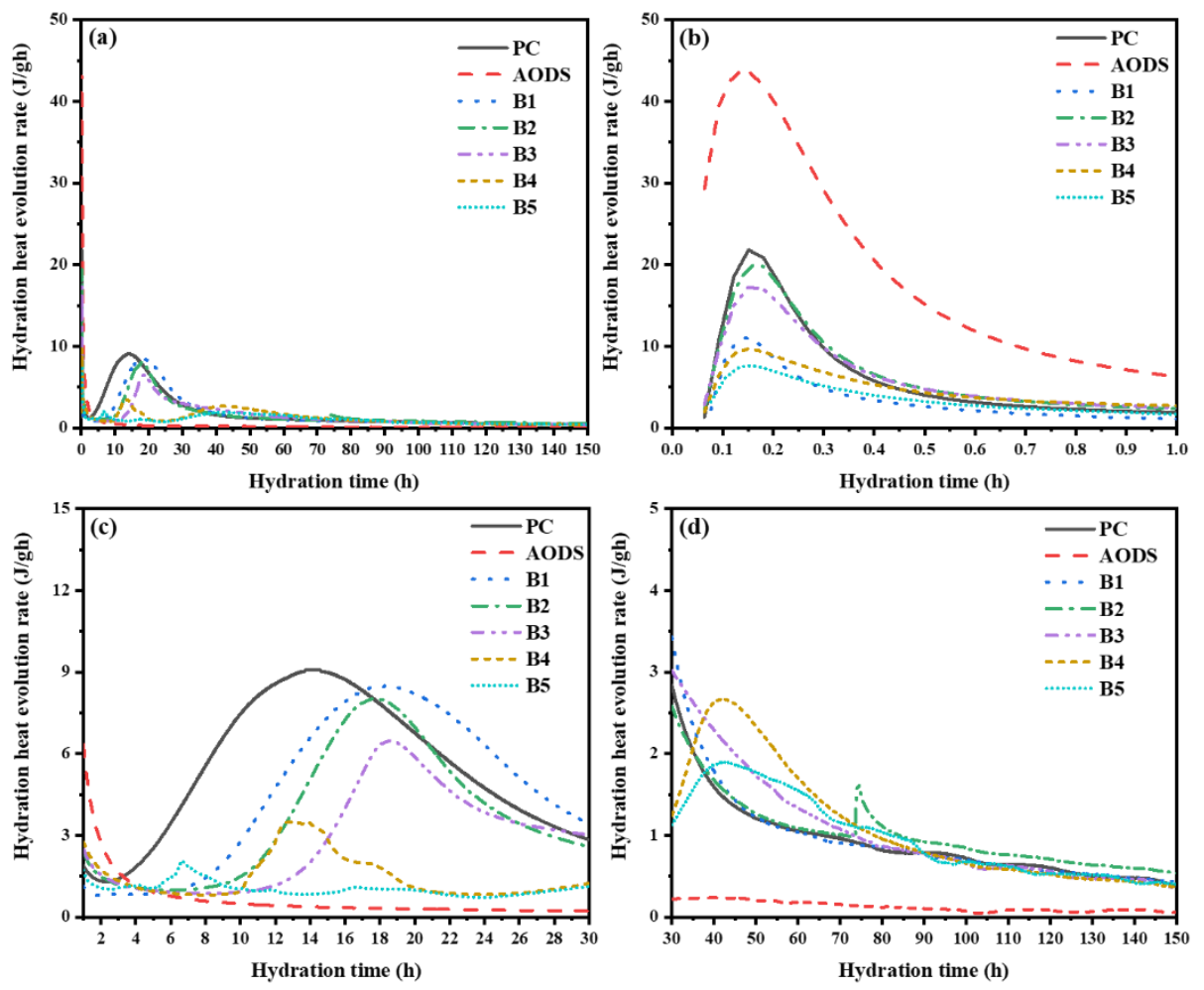

Figure 4. Hydration exothermic rate of composite pastes within (a) 0-150 h, (b) 0-1 h, (c) 1-30 h, and (d) 30-150 h. 

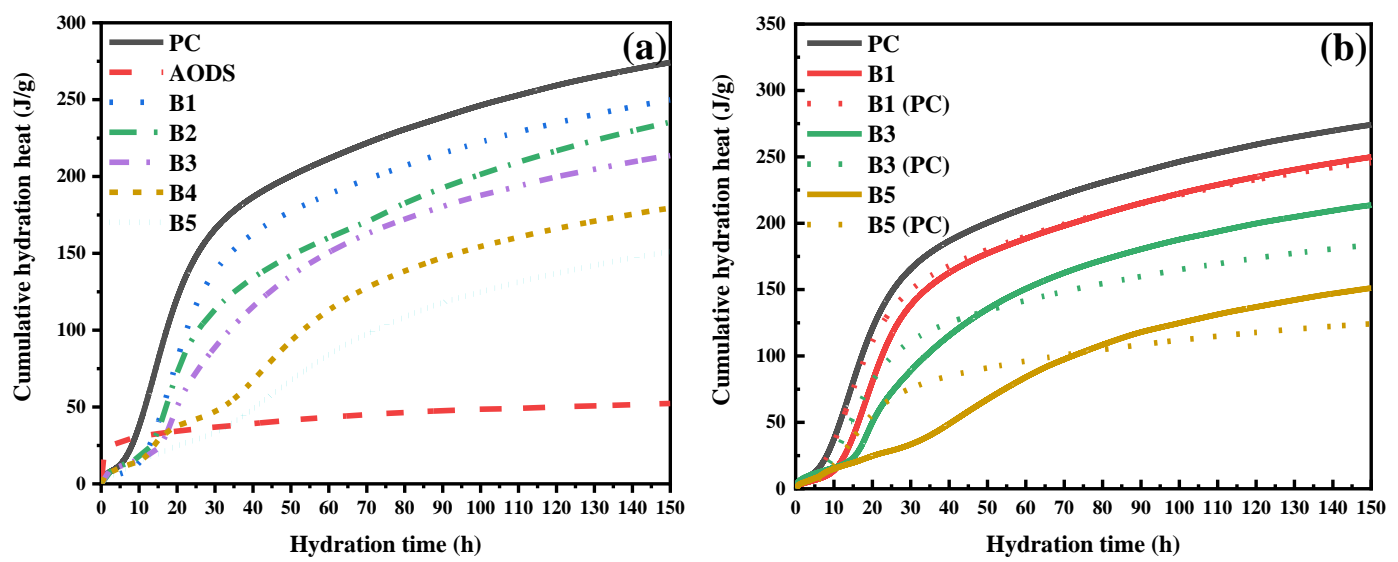

Figure 5. Cumulative hydration heat of (a) composite pastes and (b) selected referenced composite pastes.

The hydration process of pure AODS had only one exothermic peak. Owing to the greater specific surface area than cement, the AODS exothermic rate was much higher than that of PC throughout the rapid exothermic period $(0-0.15 \mathrm{~h})$ and the deceleration period $(0.15-8 \mathrm{~h})$. When the hydration of AODS entered its steady period $(>8 \mathrm{~h})$, its exothermic rate was negligible.

When the AODS dosage was lower than $33 \%$, the hydration process of composite binders had a similar trend to pure cement. Two exothermic peaks could be observed in the hydration exothermic rate patterns of B1, B2, as well as B3. While when AODS dosage was higher than $44 \%$, the hydration process of binders was more complicated, and three exothermic peaks could be observed for B4 and B5. The hydration steady period was continuously delayed as the AODS dosage increased, which accords with the results of the time setting analysis. For all composite binders, the exothermic rates decreased gradually during the deceleration period owing to the reduction in the surface area of the hydrating PC and AODS grains.

As shown in Figure 5a, the total heat release values for all composite binders were lower than that of pure $\mathrm{PC}$, which was mainly related to differences of mineralogical composition between AODS and PC. The hydraulic capacity of the mineral phases in AODS, such as $\gamma-\mathrm{C}_{2} \mathrm{~S}$, merwinite, $\mathrm{Mg}$-Cr spinel, and fluorite, have been reported to be rather limited [28,42]. As the main hydratable mineral phase in AODS, $\beta-C_{2} S^{\prime}$ s hydration efficiency was much lower than that of $C_{3} S$ [47]. The cumulative hydration heat in $150 \mathrm{~h}$ decreased from $274 \mathrm{~J} / \mathrm{g}$ for pure PC to $148 \mathrm{~J} / \mathrm{g}$ for the binder B5.

The theoretical heat release values of the cement part in the composite binders were calculated using pure PC experimental data as a reference, and the comparison curves are shown in Figure $5 \mathrm{~b}$ (take B1, B3, and B5 into account). The cumulative hydration released heat of composite binders was not as high as that of the cement part initially and then surpassed it. The intersection point would be delayed with the increase of AODS dosage. It can be concluded that the AODS had a certain hindrance to the hydration of the cement part in the early stage. According to studies of Zheng et al. [48] as well as Péra et al. [49], the mechanism of AODS substitutes effect on the retardation of cement hydration was related to its higher $\mathrm{MgO}$ content. When the hydration progressed to a certain degree, the cementitious minerals in the cement part enter an acceleration hydration period, plus the contribution of AODS hydration, and the cumulative hydration heat of composite binders surpassed that of the cement part. This indicated that the cementitious contribution of AODS was mainly manifest in the latter stage of hydration.

\subsubsection{Hydration Products}

Figure 6 illustrates the FT-IR spectrums of the composite B4's pastes with different curing ages. The three spectrums showed bands at $3640 \mathrm{~cm}^{-1}, 3435 \mathrm{~cm}^{-1}, 1638 \mathrm{~cm}^{-1}, 1440 \mathrm{~cm}^{-1}, 1422 \mathrm{~cm}^{-1}, 940 \mathrm{~cm}^{-1}$, $875 \mathrm{~cm}^{-1}$, and $500 \mathrm{~cm}^{-1}$. The sharp bands that appeared around $3640 \mathrm{~cm}^{-1}$ were associated with the asymmetric stretching vibration of the $\mathrm{OH}^{-}$groups in $\mathrm{Ca}(\mathrm{OH})_{2}$ [50]. The broad bands near $3435 \mathrm{~cm}^{-1}$ 
were related to the symmetric stretching water $\left(\left[\mathrm{Al}\left(\mathrm{OH}_{6}\right)\right]\right)$ in the ettringite [51]. The bands appearing at $940 \mathrm{~cm}^{-1}$ were attributed to the anti-symmetric stretching of the Si-O-Si bond in C-S-H gel. During the hydration curing procedure, the mineral phases with a cementitious ability, such as $\mathrm{C}_{3} \mathrm{~A}, \mathrm{C}_{3} \mathrm{~S}$, and $\beta-C_{2} S$, reacted with water to form calcium hydroxide, ettringite, and C-S-H gel. The band at $1638 \mathrm{~cm}^{-1}$ corresponded to the bending vibration of the $\mathrm{H}-\mathrm{O}-\mathrm{H}$ band for the interlayer water [52]. It can be concluded that during the pastes' hydration curing, the moisture not only participated in the mineral hydration reaction, but also transformed into interlayer water, which cannot be removed completely at $105^{\circ} \mathrm{C}$.

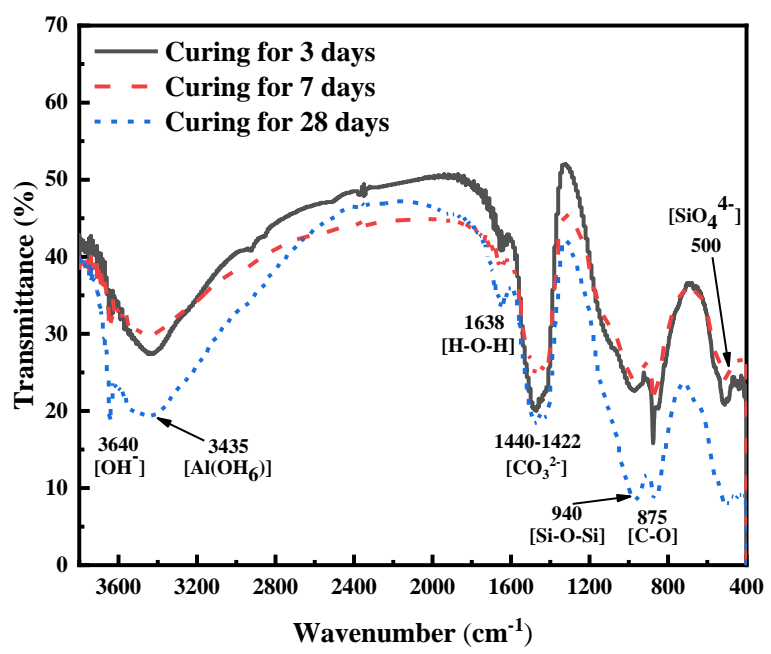

Figure 6. FT-IR spectrums of the composite B4 pastes with different curing ages.

It should be noted that the spectral region $1422-1440 \mathrm{~cm}^{-1}$ belonged to asymmetric stretching $v_{3}$ $\mathrm{CO}_{3}{ }^{2-}$ from amorphous $\mathrm{CaCO}_{3}$ [53], and the absorption peaks at $875 \mathrm{~cm}^{-1}$ assigned to the out-of-plane bending of $v_{2} \mathrm{C}-\mathrm{O}$ from calcite and vaterite [54]. The curing environment of the composite pastes met all the requirements of mineral carbonation [13]. The carbonation phases in the composite pastes included the hydration products like $\mathrm{Ca}(\mathrm{OH})_{2}$, unhydrated $\mathrm{C}_{3} \mathrm{~S}$, unhydrated $\beta-\mathrm{C}_{2} \mathrm{~S}$, and $\gamma-\mathrm{C}_{2} \mathrm{~S}$. When these phases were in contact with the dissolved $\mathrm{CO}_{2}$, the carbonation reaction occurred, and $\mathrm{CaCO}_{3}$ was produced as one of the carbonation products. The bonds of the $\mathrm{SiO}_{4}{ }^{4-}$ that appeared around $500 \mathrm{~cm}^{-1}$ corresponded to the remaining silicate phases, such as $\beta-C_{2} S, C_{3} S$, and $\gamma-C_{2} S[55,56]$.

The TG-DTG diagrams of the composite B4 paste differing in curing ages are shown in Figure 7. The DTG curves show that there were three major mass loss stages for the three aged samples with the increase of temperature. The first stage was in the temperature range of $55-300{ }^{\circ} \mathrm{C}$, corresponding to the escape of interlayer moisture as well as chemical bonding water (ettringite and C-S-H gel) $[57,58]$. Because the aged paste samples had been dried at $105^{\circ} \mathrm{C}$ for $6 \mathrm{~h}$ prior to TG-DTG analysis, the amount of interlayer water in the dried test paste samples was small. In consequence, the mass loss occurred at the initial step was mainly regarding the dehydration of the ettringite and C-S-H gel. The second mass loss stage detected in temperatures from $400{ }^{\circ} \mathrm{C}$ to $550{ }^{\circ} \mathrm{C}$ corresponded to the thermal decomposition of the $\mathrm{Ca}(\mathrm{OH})_{2}$ [59]. It can be noted that the DTG peaks for $\mathrm{Ca}(\mathrm{OH})_{2}$ were sharp, which indicated that the decomposition speed of $\mathrm{Ca}(\mathrm{OH})_{2}$ was drastic. The third mass loss stage in the temperature range of $550-950{ }^{\circ} \mathrm{C}$ corresponded to the thermal decomposition of the $\mathrm{CaCO}_{3}[60,61]$. 


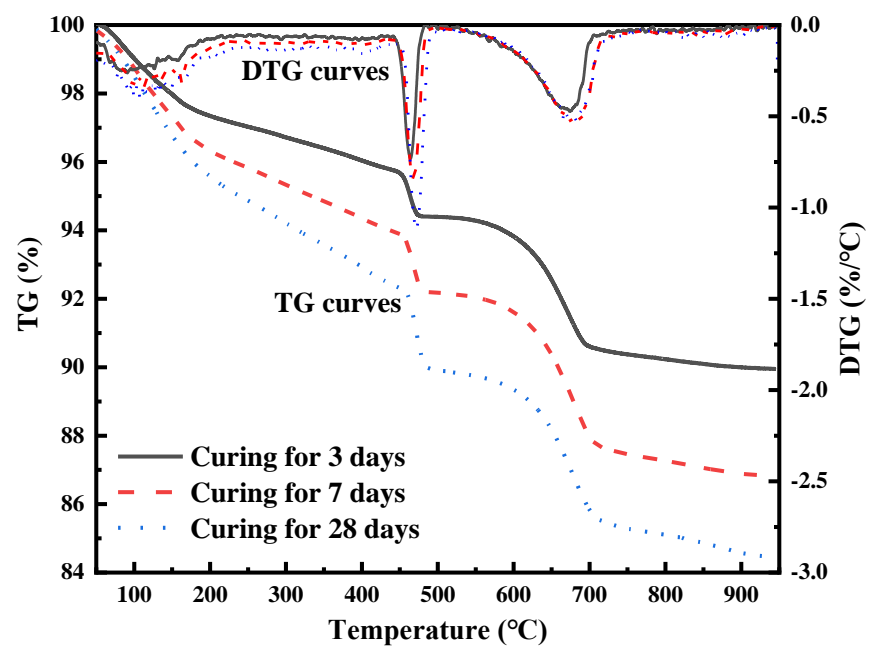

Figure 7. Thermogravimetric (TG-DTG) analysis of composite B4 pastes with different curing periods.

\subsubsection{Mechanical Strength of Mortars}

To evaluate the specific strength of the mortars manufactured with the composite binders, compressive and flexural strength examinations were carried out (GB/T 17671-1999). Figure 8 indicates the results for the strength of mortars with different curing ages. The compressive and flexural strength was an increase with curing time and decrease with AODS dosage. The mortar prepared with B1 demonstrated a 28-day compressive strength of $42.51 \mathrm{MPa}$, which satisfies the requirements for complex Portland cement (P.C) 42.5 grade specified by GB175-2007. The composite binders B2 and B3 met the requirements for P.C 32.5 grade.
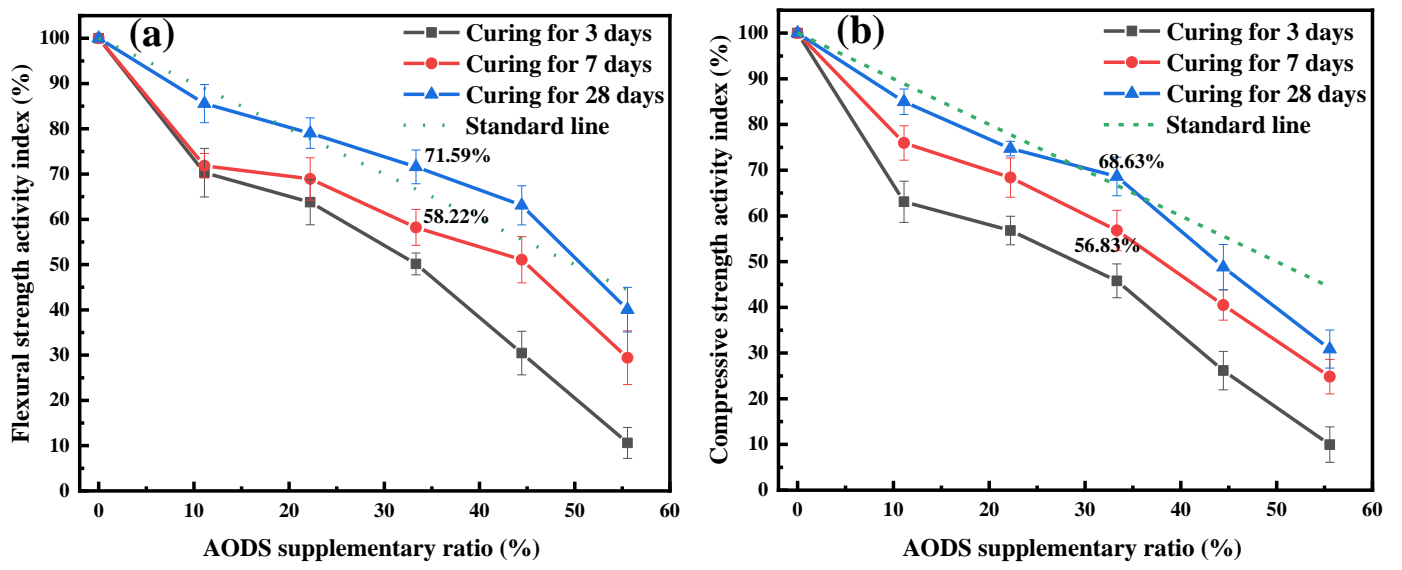

Figure 8. Flexural (a) and compressive (b) strength indexes of mortars with different AODS dosages.

The standard lines were obtained according to the PC dosages in the binders. At a curing age of 3 or 7 days, the activity indexes of the binders were not as high as that of the cement contents in the composite binders. This indicated that AODS harmed the mortar's strength in the early period. This was consistent with the results of hydration exotherm analysis. At a-28-day curing age, the activity indexes of the binders were close to, or even surpassed, the standard values. So, it can be concluded that mineral phases in the AODS hydrated and contributed to the strength of the mortars at late curing ages. In the early stage, the $\mathrm{C}_{3} \mathrm{~S}$ in the cement had undergone a hydration reaction to generate $\mathrm{Ca}(\mathrm{OH})_{2}$, making the slurry alkaline. The alkaline environment had a certain activation effect on the AODS, which accelerated the hydration of the $C_{2} S$ therein [42], and provided a favorable impact on the mortars' strength later in the process. 
The steel slag (SS) powder ready to act as a substitute in cement can be categorized into two grades in accordance with the CNS GB/T 20491-2006. It specifies that the test binder sample is prepared by mixing 30\% SS and 70\% cement by mass, and activity indexes for the Grade I SS powder ought to be $\geq 65 \%$ (curing ages of 7 days) and $\geq 80 \%$ (curing ages of 28 days), separately. For the Grade II SS powder, activity indexes ought to $\geq 55 \%$ (curing ages of 7 days) and $\geq 65 \%$ (curing ages of 28 days), respectively. The $33.33 \%$ AODS-containing composite binder (B3) was used as the test sample to determine the cementitious grade, and the results showed that AODS could fulfill the requirements of the Grade II SS powder.

\subsubsection{Morphology and Microstructure of Cured Pastes}

The SEM photos of the B4's paste with different curing times are presented in Figure 9. According to SEM images, it could be noted clearly that gel-like structures, such as the C-S-H phase, had been formed. The paste hydrated with separated flakelike morphology at the early 3 days curing stage. As the hydration curing furthered to the 7th day, a reticulated network between the separated matrix was generated. As the hydration curing prolonged to the 28th day, the paste formed a denser agglomerated structure (see Figure 9c,d). In a word, as the curing period prolonged, the composite paste's porosity decreased gradually.

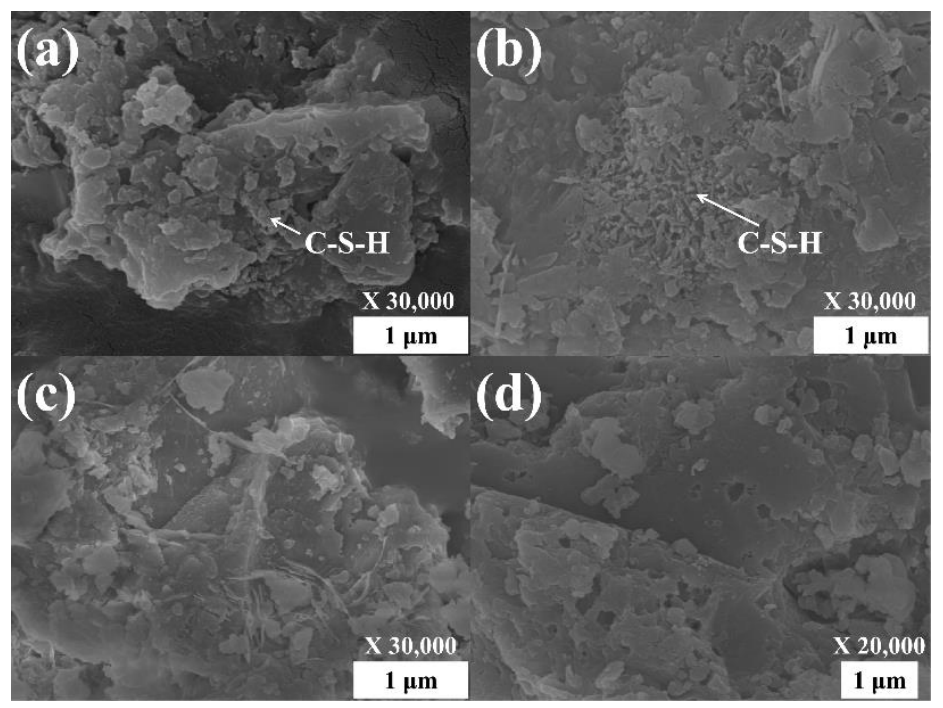

Figure 9. Scanning electron microscopy (SEM) photos of the B4's paste with a curing time of 3 days (a),

7 days $(\mathbf{b})$, and 28 days $(\mathbf{c}, \mathbf{d})$.

Figure 10 shows the SEM images of 28-day-cured pastes with different AODS dosages. Combined with Figure 9d, it could be found that when AODS dosage was lower than $44 \%$, the 28 -day-cured paste appeared as a denser agglomerated structure with few pores. B5's 28-day-cured paste was ready to form a denser agglomerated structure, and the matrix tended to stack together. With the dosage of AODS increased to 55\%, the needle-like C-S-H gel between the substrates was visible, and the reticulated networks far from enough to tightly connect the matrix. As the previous analysis shows, AODS had a much lower cementitious activity than PC, the paste with a larger AODS dosage cannot produce enough gelling substance to connect the matrix very well like the low AODS content pastes. 


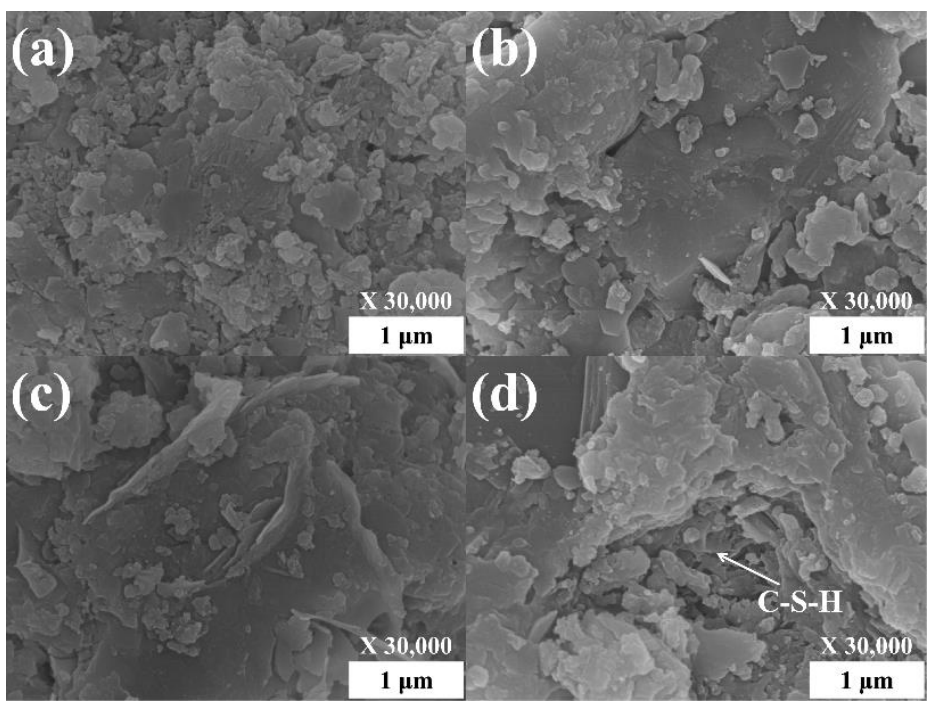

Figure 10. SEM photos of 28-days cured pastes with AODS dosage of $11 \%(\mathbf{a}), 22 \%(\mathbf{b}), 33 \%(\mathbf{c})$, and $55 \%(\mathbf{d})$.

\subsection{The Chromium Leachability of Composite Pastes}

\subsubsection{Effects of Curing Time on Chromium Leachability}

Figure 11 presents the evolution in $\mathrm{pH}, \mathrm{Eh}$, and electrical conductivity value of the leachates obtained from the 20-day sequential leaching test. As shown in Figure 11a, with the increasing of curing time, the leachate $\mathrm{pH}$ of the composite pastes increased, while their Eh decreased. Compared to the non-hydrated binder, the leachate $\mathrm{pH}$ of the 28-day-cured binder increased by $\sim 0.5 \mathrm{pH}$ units, which attributed to the continuous generation of $\mathrm{Ca}(\mathrm{OH})_{2}$ during the curing procedure. $\mathrm{More} \mathrm{Ca}(\mathrm{OH})_{2}$ existed in the 28-day-cured paste, leading to a higher $\mathrm{pH}$ of the leachates. According to the study by [62], Eh is negatively correlated with $\mathrm{pH}$, but positively correlated with the dissolved oxygen (DO) concentration. During the sequential leaching procedure, the increasing $\mathrm{pH}$ caused by the dissolution of $\mathrm{Ca}(\mathrm{OH})_{2}$, coupled with the daily DO brought in during sampling and replacement of the leachates, increased the Eh of the leachates.
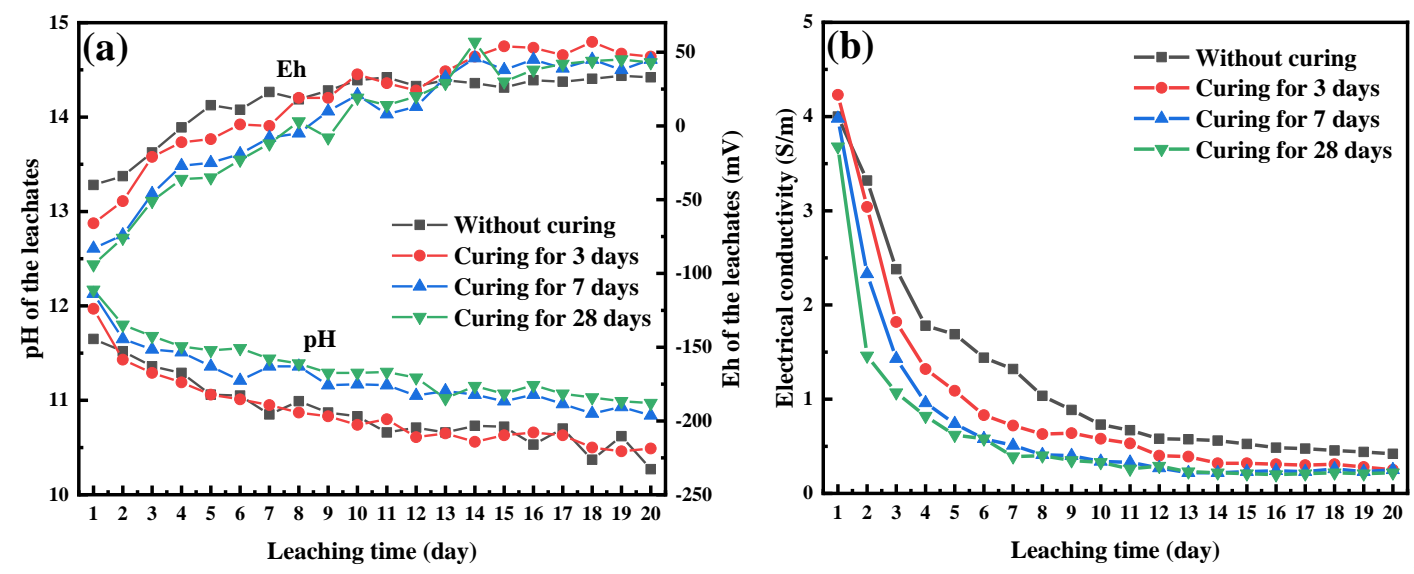

Figure 11. $\mathrm{pH}(\mathbf{a})$, Eh (a), and electrical conductivity (b) evolutions of the leachates for pastes with different curing time.

As shown in Figure 11b, the electrical conductivity, that could be used to measure the total ion leachability of composite pastes [63], sharply decreased from $\sim 4.0 \mathrm{~S} / \mathrm{m}$ to $<0.5 \mathrm{~S} / \mathrm{m}$. This finding indicated a fact that numerous ions were rapidly released from composite pastes at the early leaching stage. As the leaching continued, a stage of sustained and slow release of ions was reached. Moreover, 
it could be also found that electrical conductivity decreased with the increasing of the curing time. Furthered curing could generate enough hydration products, mainly C-S-H gel, to fill and adhere to the gaps between the matrix. The formed dense surface can physically encapsulate internal hydrolysable minerals. Meanwhile, the generated C-S-H gel could chemically combine with $\mathrm{Ca}^{2+}$. The combined effect of physical encapsulation and chemical combination led to a decrease in electrical conductivity.

The evolution of chromium concentrations in leachates of the pastes with four curing periods is illustrated in Figure 12. The releasing trend of chromium from the composite paste at each curing period was relatively consistent. In the period of the initial leaching, the release rate of chromium in the dry powder increased rapidly and reached to the maximum value of $0.41 \mathrm{mg} \cdot \mathrm{kg}^{-1} \cdot \mathrm{d}^{-1}$ at the fourth leaching day, which was much faster than the other three cured pastes. After reaching peaks, the chromium leaching rates experienced a rapid decline and reached a stable value at the latter leaching stage. The minimum chromium leaching rate in dry powder, 3-, 7-, and 28-day-cured paste fluctuated around $6.4 \times 10^{-2} \mathrm{mg} \cdot \mathrm{kg}^{-1} \cdot \mathrm{d}^{-1}, 4.2 \times 10^{-2} \mathrm{mg} \cdot \mathrm{kg}^{-1} \cdot \mathrm{d}^{-1}, 4.0 \times 10^{-2} \mathrm{mg} \cdot \mathrm{kg}^{-1} \cdot \mathrm{d}^{-1}$, and $3.8 \times 10^{-2} \mathrm{mg} \cdot \mathrm{kg}^{-1} \cdot \mathrm{d}^{-1}$, separately. The accumulated leaching amount of chromium was $3.6 \mathrm{mg} \cdot \mathrm{kg}^{-1}, 3.0 \mathrm{mg} \cdot \mathrm{kg}^{-1}, 2.6 \mathrm{mg} \cdot \mathrm{kg}^{-1}$, and $2.0 \mathrm{mg} \cdot \mathrm{kg}^{-1}$ in 20 days, corresponding to the curing time of paste for $0,3,7$, and 28 days, respectively (see Figure 12b). It could be concluded that with the curing time increasing, the leachability of chromium from the composite declined. By analyzing Figure 9, it became known that if the curing time was shorter than 28 days, the dense microscopic morphology cannot be formed. In this case, the leachate cannot be effectively blocked from the Cr-bearing phases. The S/S efficiency of cementitious behavior on $\mathrm{Cr}$ leachability was increased continuously with curing time [64]. The generation of this C-S-H gel took place in the pores of the hardened composite pastes' matrix. With the extension of the curing period, the continuously generated C-S-H gel reduced the porosity and hindered the contact of chromium-bearing soluble phases with the solution to elute $\mathrm{Cr}$.
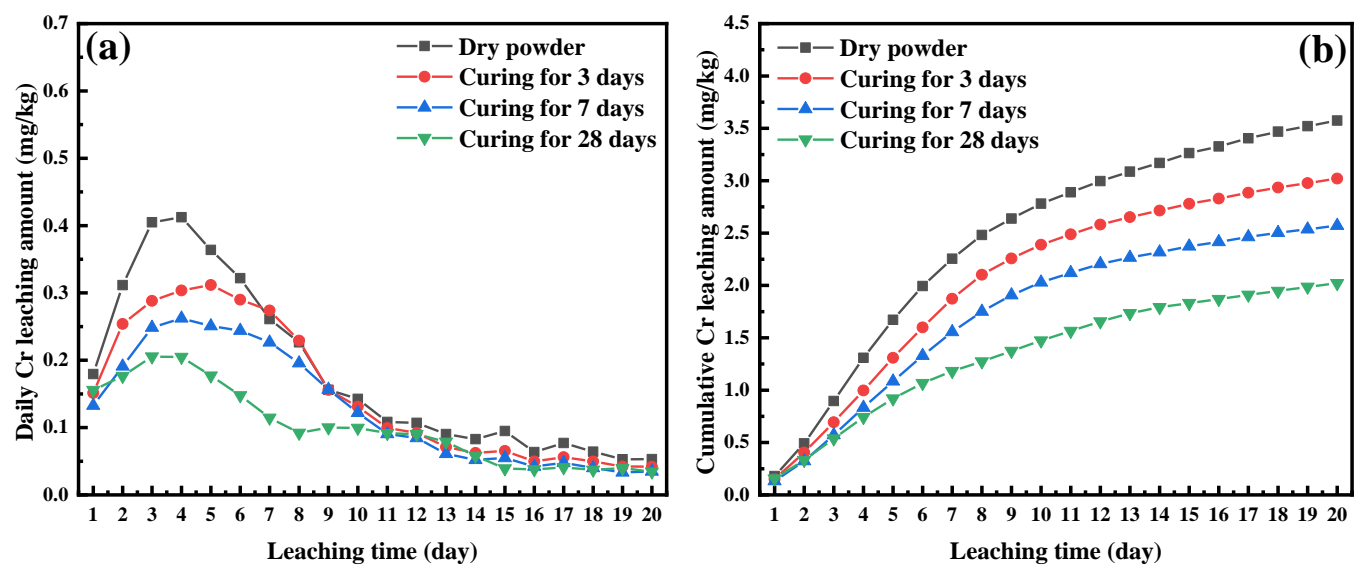

Figure 12. Evolution of (a) daily and (b) cumulative Cr concentrations in leachates for pastes with different curing times.

\subsubsection{Effects of AODS's Dosage on Chromium Leachability}

The evolution of chromium leaching ratio of pastes with different AODS dosages is presented in Figure 13. It could be seen that the chromium leaching ratio significantly increased with the increase of AODS dosage. The P5 released more than 10\% chromium after 20-day-leaching, while the P3 released only about $5 \%$ chromium. When the AODS dosage was lower than $22 \%$, the daily chromium released concentrations from P1 (the entire leaching cycle) and P2 (after the $5^{\text {th }}$ leaching day) were below the detection limit of ICP-OES $(0.004 \mathrm{mg} / \mathrm{L})$, so their data were not presented completely in Figure 13b. 

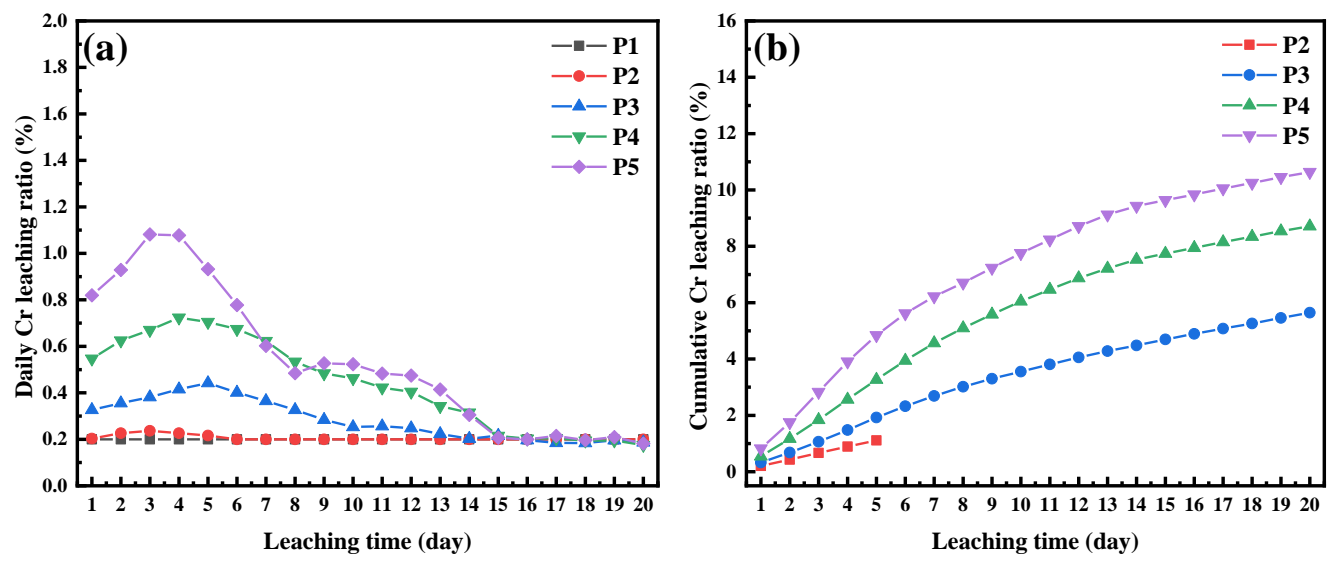

Figure 13. Evolution of (a) daily and (b) cumulative $\mathrm{Cr}$ leaching ratio from pastes with different AODS dosages (The daily $\mathrm{Cr}$ released concentrations from P1 and P2 were below the detection limit, so their data were not presented completely).

As shown in Figure 10, when the AODS dosage was higher than $44 \%$, the hydration products failed to fill or bond the porosity between the matrix. As cement incorporation increased, large amounts of hydration products were produced after 28-day-curing. Some of the gelling substances, mainly C-S-H gel, filled the pores between the matrix and formed a dense surface.

Sufficient cement incorporation and long enough curing time were two keys to the successful implementation of $\mathrm{S} / \mathrm{S}$ for chromium in composite pastes. Both of these can increase the hydration rate of the composite material and generate more hydration products. A significant role in the $S / S$ was attributed to C-S-H gel - the primary hydration outcome of the hardened pastes [54]. An increasing amount of C-S-H gel leads to lower permeability. Physical encapsulation of the C-S-H gel prevented the leachate in contact with chromium-bearing phases and decreased the dissolution rate of these phases, and thereby stabilized the chromium.

\section{Conclusions}

In this study, the cementitious properties of AOD slag and the S/S efficiency of chromium in cement-based composite cementitious materials with various curing conditions were investigated. Some conclusions have been found:

1. The most beneficial AODS mineral phase for cementitious behavior was $\beta-C_{2} S$. The utilization of a higher AODS dosage in composite binders increased the water requirement, prolonged the setting time, weakened the hydration heat, and decreased the strength indexes.

2. Although the AODS possessed limited cementitious properties, it can fulfill the standard of the Grade II SS powder for cement and concrete.

3. With lower AODS dosage and longer curing time, the S/S efficiency for chromium in the composite paste was improved.

Author Contributions: Conceptualization, J.-G.L.; methodology, Y.-J.W.; software, Y.-Z.Z.; validation, Y.-J.W., J.-G.L. and Y.-N.Z.; formal analysis, Y.-J.W.; investigation, Y.-J.W. and Y.-Z.Z.; resources, Y.-N.Z. and J.-G.L.; data curation, Y.-J.W.; writing — original draft preparation, Y.-J.W.; writing—review and editing, Y.-N.Z.; visualization, Y.-J.W.; supervision, J.-G.L.; project administration, J.-G.L.; funding acquisition, Y.-N.Z. All authors have read and agreed to the published version of the manuscript.

Funding: This research was funded by the National Natural Science Foundation of China $($ No. 51704119, 51574108) and the Key Research and Development Project of Tangshan (No. 19140205F).

Acknowledgments: We wish to express our gratitude to the members of our research team, Wei Wang, Fu Zheng, Jin Li, Yi-Tong Wang, and Qing-Zhong Zhao.

Conflicts of Interest: The authors declare no conflict of interest. The funders had no role in the design of the study; in the collection, analyses, or interpretation of data; in the writing of the manuscript, or in the decision to publish the results. 


\section{References}

1. Iacobescu, R.I.; Angelopoulos, G.N.; Jones, P.T.; Blanpain, B.; Pontikes, Y. Ladle metallurgy stainless steel slag as a raw material in Ordinary Portland Cement production: A possibility for industrial symbiosis. J. Clean. Prod. 2016, 112, 872-881. [CrossRef]

2. Adegoloye, G.; Beaucour, A.L.; Ortola, S.; Noumowé, A. Concretes made of EAF slag and AOD slag aggregates from stainless steel process: Mechanical properties and durability. Construct. Build. Mater. 2015, 76, 313-321. [CrossRef]

3. Zhang, S.; Zhang, Y.L.; Qu, Z.M. Physicochemical property and chromium leaching behavior in different environments of glass ceramics prepared from AOD stainless steel slag. J. Alloy. Compd. 2019, 805, 1106-1116. [CrossRef]

4. Kim, Y.-M.; Hong, S.-H. Influence of minor ions on the stability and hydration rates of $\beta$-dicalcium silicate. J. Am. Ceram. 2004, 87, 900-905. [CrossRef]

5. Kriskova, L.; Eroli, M.; Iacobescu, R.I.; Onisei, S.; Vecchiocattivi, F.; Pontikes, Y. Transformation of stainless steel slag toward a reactive cementitious binder. J. Am. Ceram. Soc. 2017, 101, 1727-1736. [CrossRef]

6. Li, J.G.; Liu, B.; Zeng, Y.N.; Wang, Z.M.; Gao, Z.Y. Maximum availability and mineralogical control of chromium released from AOD slag. Environ. Monit. Assess. 2017, 189, 113. [CrossRef]

7. Liu, B.; Li, J.G.; Zeng, Y.N.; Wang, Z.M. Toxicity assessment and geochemical model of chromium leaching from AOD slag. Chemosphere 2016, 114, 2052-2057. [CrossRef]

8. DesMarais, T.L.; Costa, M. Mechanisms of chromium-induced toxicity. Curr. Opin. Toxicol. 2019, 14, 1-7. [CrossRef]

9. Simonsen, A.M.T.; Solismaa, S.; Hansen, H.K.; Jensen, P.E. Evaluation of mine tailings' potential as supplementary cementitious materials based on chemical, mineralogical and physical characteristics. Waste Manag. 2020, 102, 710-721. [CrossRef]

10. Herrero, T.; Vegas, I.J.; Santamaría, A.; San-José, J.T.; Skaf, M. Effect of high-alumina ladle furnace slag as cement substitution in masonry mortars. Constr. Build. Mater. 2016, 123, 404-413. [CrossRef]

11. Mladenovič, A.; Mirtič, B.; Meden, A.; Zalar Serjun, V. Calcium aluminate rich secondary stainless steel slag as a supplementary cementitious material. Constr. Build. Mater. 2016, 116, 216-225. [CrossRef]

12. Shi, C. Steel slag-its production, processing, characteristics, and cementitious properties. J. Mater. Civ. Eng. 2004, 16, 230-236. [CrossRef]

13. Wang, Y.-J.; Zeng, Y.-N.; Li, J.-G.; Zhang, Y.-Z.; Zhang, Y.-J.; Zhao, Q.-Z. Carbonation of argon oxygen decarburization stainless steel slag and its effect on chromium leachability. J. Clean. Prod. 2020, 256, 120377. [CrossRef]

14. Wang, Q.; Shi, M.; Yang, J. Influence of classified steel slag with particle sizes smaller than $20 \mu \mathrm{m}$ on the properties of cement and concrete. Constr. Build. Mater. 2016, 123, 601-610.

15. Park, B.; Moon, E.-J.; Choi, Y.C. Investigation of microstructure and mechanical performance of carbon-capture binder using AOD stainless steel slag. Constr. Build. Mater. 2020, 242, 118174. [CrossRef]

16. Belhadj, E.; Diliberto, C.; Lecomte, A. Properties of hydraulic paste of basic oxygen furnace slag. Cement Concr. Comp. 2014, 45, 15-21. [CrossRef]

17. Moon, E.-J.; Choi, Y.C. Carbon dioxide fixation via accelerated carbonation of cement-based materials: Potential for construction materials applications. Constr. Build. Mater. 2019, 199, 676-687. [CrossRef]

18. Saito, T.; Sakai, E.; Morioka, M.; Otsuki, N. Carbonation of $\gamma-\mathrm{Ca} 2 \mathrm{SiO} 4$ and the Mechanism of Vaterite Formation. J. Adv. Concr. Technol. 2010, 8, 273-280. [CrossRef]

19. Mabudo, G.M.; Lee, S.; Kang, S.; Song, M. Physical properties and carbon dioxide capture of synthetic gamma- $\mathrm{C}_{2} \mathrm{~S}$ cement composites in the early days of curing. Mag. Concr. Res. 2016, 68, 1079-1084. [CrossRef]

20. Gupta, T.; Sachdeva, S.N. Laboratory investigation and modeling of concrete pavements containing AOD steel slag. Cement Concr. Res. 2019, 124, 105808. [CrossRef]

21. Carvalho, S.Z.; Vernilli, F.; Almeida, B.; Demarco, M.; Silva, S.N. The recycling effect of BOF slag in the portland cement properties. Resour. Conserv. Recy. 2017, 127, 216-220. [CrossRef]

22. Ramakrishnan, K.; Pugazhmani, G.; Sripragadeesh, R.; Muthu, D.; Venkatasubramanian, C. Experimental study on the mechanical and durability properties of concrete with waste glass powder and ground granulated blast furnace slag as supplementary cementitious materials. Constr. Build. Mater. 2017, 156, 739-749. [CrossRef] 
23. Franco de Carvalho, J.M.; Fontes, W.C.; Felipe de Azevedo, C.; Brigolini, G.J.; Schmidt, W.; Fiorotti Peixoto, R.A. Enhancing the eco-efficiency of concrete using engineered recycled mineral admixtures and recycled aggregates. J. Clean. Prod. 2020, 257, 120530. [CrossRef]

24. Isteri, V.; Ohenoja, K.; Hanein, T.; Kinoshita, H.; Tanskanen, P.; Illikainen, M.; Fabritius, T. Production and properties of ferrite-rich CSAB cement from metallurgical industry residues. Sci. Total Environ. 2020, 712, 136208. [CrossRef] [PubMed]

25. Shen, H.; Forssberg, E.; Nordström, U. Physicochemical and mineralogical properties of stainless steel slags oriented to metal recovery. Resour. Conserv. Recy. 2004, 40, 245-271. [CrossRef]

26. Gupta, T.; Sachdeva, S.N. Experimental study and modeling of concrete containing AOD steel slag for pavements. Arab. J. Sci. Eng. 2020, 45, 8111-8127. [CrossRef]

27. Baciocchi, R.; Costa, G.; Polettini, A.; Pomi, R. Influence of particle size on the carbonation of stainless steel slag for CO2 storage. Energy Procedia 2009, 1, 4859-4866. [CrossRef]

28. Jiang, Y.; Ling, T.-C.; Shi, C.; Pan, S.-Y. Characteristics of steel slags and their use in cement and concrete-A review. Resour. Conserv. Recy. 2018, 136, 187-197. [CrossRef]

29. Guo, B.; Liu, B.; Yang, J.; Zhang, S. The mechanisms of heavy metal immobilization by cementitious material treatments and thermal treatments: A review. J. Environ. Manag. 2017, 193, 410-422. [CrossRef]

30. Kogbara, R.B.; Al-Tabbaa, A. Mechanical and leaching behaviour of slag-cement and lime-activated slag stabilised/solidified contaminated soil. Sci. Total Environ. 2011, 409, 2325-2335. [CrossRef]

31. Wang, L.; Chen, L.; Tsang, D.C.W.; Zhou, Y.; Rinklebe, J.; Song, H.; Kwon, E.E.; Baek, K.; Sik Ok, Y. Mechanistic insights into red mud, blast furnace slag, or metakaolin-assisted stabilization/solidification of arsenic-contaminated sediment. Environ. Int. 2020, 136, 106194. [CrossRef] [PubMed]

32. Chen, Q.Y.; Tyrer, M.; Hills, C.D.; Yang, X.M.; Carey, P. Immobilisation of heavy metal in cement-based solidification/stabilisation: A review. Waste Manag. 2008, 29, 390-403. [CrossRef] [PubMed]

33. Wang, L.; Cho, D.-W.; Tsang, D.C.W.; Cao, X.; Hou, D.; Shen, Z.; Alessi, D.S.; Sik Ok, Y.; Poon, C.S. Green remediation of $\mathrm{As}$ and $\mathrm{Pb}$ contaminated soil using cement-free clay-based stabilization/solidification. Environ. Int. 2019, 126, 336-345. [CrossRef] [PubMed]

34. Kiventerä, J.; Piekkari, K.; Isteri, V.; Ohenoja, K.; Tanskanen, P.; Illikainen, M. Solidification/stabilization of gold mine tailings using calcium sulfoaluminate-belite cement. J. Clean. Prod. 2019, 239, 118008. [CrossRef]

35. Su, P.; Zhang, J.; Li, Y. Solidification/stabilization of stainless steel pickling residue with aluminum potassium sulfate amended fly ash. J. Clean. Prod. 2019, 234, 400-409. [CrossRef]

36. Wang, L.; Geddes, D.A.; Walkley, B.; Provis, J.L.; Mechtcherine, V.; Tsang, D.C.W. The role of zinc in metakaolin-based geopolymers. Cement Concr. Res. 2020, 136, 106194. [CrossRef]

37. Meena, A.H.; Kaplan, D.I.; Powell, B.A.; Arai, Y. Chemical stabilization of chromate in blast furnace slag mixed cementitious materials. Chemosphere 2015, 138, 247-252. [CrossRef]

38. Panda, C.R.; Mishra, K.K.; Panda, K.C.; Nayak, B.D.; Nayak, B.B. Environmental and technical assessment of ferrochrome slag as concrete aggregate material. Constr. Build. Mater. 2013, 49, 262-271. [CrossRef]

39. Serjun, V.Z.; Mladenovič, A.; Mirtič, B.; Meden, A.; Ščančar, J.; Milačič, R. Recycling of ladle slag in cement composites: Environmental impacts. Waste Manag. 2015, 43, 376-385. [CrossRef]

40. Zhao, Q.; Liu, C.; Cao, L.; Zheng, X.; Jiang, M. Stability of chromium in stainless steel slag during cooling. Minerals 2018, 8, 445. [CrossRef]

41. Wang, Q.; Wang, D.; Zhuang, S. The soundness of steel slag with different free $\mathrm{CaO}$ and $\mathrm{MgO}$ contents. Constr. Build. Mater. 2017, 151, 138-146. [CrossRef]

42. Kriskova, L.; Pontikes, Y.; Cizer, Ö.; Mertens, G.; Veulemans, W.; Geysen, D.; Jones, P.T.; Vandewalle, L.; Balen, K.V.; Blanpain, B. Effect of mechanical activation on the hydraulic properties of stainless steel slags. Cement Concr. Res. 2012, 42, 778-788. [CrossRef]

43. Kim, E.; Spooren, J.; Broos, K.; Nielsen, P.; Horckmans, L.; Geurts, R.; Vrancken, K.C.; Quaghebeur, M. Valorization of stainless steel slag by selective chromium recovery and subsequent carbonation of the matrix material. J. Clean. Prod. 2016, 117, 221-228. [CrossRef]

44. Motz, H.; Geiseler, J. Products of steel slags an opportunity to save natural resources. Waste Manag. 2001, 21, 285-293. [CrossRef]

45. Liu, S.; Li, L. Influence of fineness on the cementitious properties of steel slag. J. Therm. Anal. Calorim. 2014, 117, 629-634. [CrossRef] 
46. Sheen, Y.-N.; Wang, H.-Y.; Sun, T.-H. A study of engineering properties of cement mortar with stainless steel oxidizing slag and reducing slag resource materials. Constr. Build. Mater. 2013, 40, 239-245. [CrossRef]

47. EI-Didamony, H.; Sharara, A.M.; Helmy, I.M.; El-Aleem, S.A. Hydration characteristics of $\beta-C_{2} S$ in the presence of some accelerators. Cement Concr. Res. 1996, 26, 1179-1187. [CrossRef]

48. Zheng, L.; Xuehua, C.; Mingshu, T. Hydration and setting time of MgO-type expansive cement. Cement Concr. Res. 1992, 22, 1-5. [CrossRef]

49. Péra, J.; Ambroise, J.; Chabannet, M. Properties of blast-furnace slags containing high amounts of manganese. Cement Concr. Res. 1999, 29, 171-177. [CrossRef]

50. Shi, T.; Gao, Y.; Corr, D.J.; Shah, S.P. FTIR study on early-age hydration of carbon nanotubes-modified cement-based materials. Adv. Cem. Res. 2019, 31, 353-361. [CrossRef]

51. Wang, W.; Shao, Y.; Hou, H.; Zhou, M. Synthesis and thermodynamic properties of arsenate and sulfate-arsenate ettringite structure phases. PLOS ONE 2017, 12, e0182160. [CrossRef] [PubMed]

52. Alotaibi, J.; Saji, S.; Swain, M.V. FTIR characterization of the setting reaction of biodentine ${ }^{\mathrm{TM}}$. Dent. Mater. 2018, 34, 1645-1651. [CrossRef] [PubMed]

53. Cheng, M.; Sun, S.; Wu, P. Microdynamic changes of moisture-induced crystallization of amorphous calcium carbonate revealed via in situ FTIR spectroscopy. Phys. Chem. Chem. Phys. 2019, 21, 21882-21889. [CrossRef] [PubMed]

54. Chen, Z.; Lee, Y.; Cho, H.; Lee, H.; Lim, S. Improvement in carbonation resistance of portland cement mortar incorporating $\gamma$-dicalcium silicate. Adv. Mater. Sci. Eng. 2019, 2019, 1-10. [CrossRef]

55. Zhang, N.; Wu, L.; Liu, X.; Zhang, Y. Structural characteristics and cementitious behavior of basic oxygen furnace slag mud and electric arc furnace slag. Constr. Build. Mater. 2019, 219, 11-18. [CrossRef]

56. Chang, J.; Cang, X.; Zhang, Y.Y.; Wang, D. Foaming characteristics and microstructure of aerated steel slag block prepared by accelerated carbonation. Constr. Build. Mater. 2019, 209, 222-233. [CrossRef]

57. Chang, J.; Fang, Y.; Shang, X. The role of $\beta-C_{2} S$ and $\gamma-C_{2} S$ in carbon capture and strength development. Mater. Struct. 2016, 49, 4417-4424. [CrossRef]

58. Zhang, N.; Li, H.; Zhao, Y.; Liu, X. Hydration characteristics and environmental friendly performance of a cementitious material composed of calcium silicate slag. J. Hazard Mater. 2016, 306, 67-76. [CrossRef]

59. Kumar, S.; Bandopadhyay, A.; Alex, T.C.; Kumar, R. Influence of mechanical activation on the synthesis and hydraulic activity of calcium dialuminate. Ceram. Int. 2006, 32, 555-560. [CrossRef]

60. Wang, L.; Chen, L.; Tsang, D.C.W.; Li, J.-S.; Yeung, T.L.Y.; Ding, S.M.; Poon, C.S. Green remediation of contaminated sediment by stabilization/solidification with industrial by-products and $\mathrm{CO}_{2}$ utilization. Sci. Total Environ. 2018, 631, 1321-1327. [CrossRef]

61. Jeong, Y.; Yum, W.S.; Moon, J.; Oh, J.E. Utilization of precipitated $\mathrm{CaCO}_{3}$ from carbon sequestration of industrially emitted $\mathrm{CO}_{2}$ in cementless CaO-activated blast-furnace slag binder system. J. Clean. Prod. 2017, 166, 649-659. [CrossRef]

62. Xu, H.C.; Xu, X.J.; Wang, K.; Huang, J.G. An analysis of factors affecting the oxidation reduction potential in drinking water. J. Univ. Sci. Technol. Suzhou Eng. Technol. 2007, 20, 63-66.

63. Chen, Y.-L.; Ko, M.-S.; Lai, Y.-C.; Chang, J.-E. Hydration and leaching characteristics of cement pastes made from electroplating sludge. Waste Manag. 2011, 31, 1357-1363. [CrossRef] [PubMed]

64. Giergiczny, Z.; Król, A. Immobilization of heavy metals ( $\mathrm{Pb}, \mathrm{Cu}, \mathrm{Cr}, \mathrm{Zn}, \mathrm{Cd}, \mathrm{Mn})$ in the mineral additions containing concrete composites. J. Hazard Mater. 2008, 160, 247-255. [CrossRef] [PubMed]

(C) 2020 by the authors. Licensee MDPI, Basel, Switzerland. This article is an open access article distributed under the terms and conditions of the Creative Commons Attribution (CC BY) license (http://creativecommons.org/licenses/by/4.0/). 